\title{
PENERAPAN MODEL PEMBELAJARAN EXPERIENTAL LEARNING TERHADAP PERUBAHAN KONSEPTUAL SISWA PADA MATERI SIFAT-SIFAT CAHAYA
}

\section{THE APPLICATIONS EXPERIENTAL LEARNING MODEL TO CONCEPTUAL CHANGES PROPERTIES OF LIGHT}

\author{
Gilang Camilla Alamanda \\ Guru Sekolah Dasar Negeri Pameuntasan 1 Kabupaten Bandung \\ E-mail: gilangalamanda@yahoo.com
}

\begin{abstract}
ABSTRAK
Penelitian ini dilatarbelakangi oleh lemahnya kualitas pembelajaran atau pembelajaran yang lebih mementingkan isi daripada proses sehingga penerapan pembelajaran khususnya pada materi sifat-sifat cahaya hanya mengandalkan hapalan-hapalan konsep-konsep yang dapat mengakibatkan siswa tidak bisa menghubungkan konsep-konsep yang sedang dipelajarinya. Materi sifat-sifat cahaya merupakan materi yang bersifat fenomena sehingga dalam penerapannya diperlukan sebuah tahapan-tahapan penerapan pembelajaran yang dipusatkan kepada siswa yakni slah satunya dengan penerapan model pembelajaran Experiental Learning. Metode penelitian yang digunakan dalam penelitian ini adalah metode kuasi eksperimen dengan desain pre-test post-test control group design. Sampel penelitian ini adalah siswa kelas V pada salah satu komplek SD Negeri yang ada di Kecamatan Kutawaringin Kabupaten Bandung, jumlah seluruh siswa kelas V yang ada pada SD Negeri tersebut sebanyak 161 siswa. Teknik pengambilan sampel dilakukan secara acak tanpa mengubah kondisi kelas. Sampel kelas kontrol diambil dari kelas VA yang berjumlah 31 siswa, dan sampel kelas eksperimen diambil dari kelas VB yang berjumlah 31 siswa. Instrumen yang digunakan terdiri dari tes pemahaman konsep, lembar keterlaksanaan model pembelajaran Experiental Learning, dan lembar angket tanggapan siswa. Hasil penelitian menunjukkan bahwa 1). Pembelajaran Experiental Learning merubah pemahaman konsep siswa dilihat dari nilai rata-rata kelas yang meningkat saat pretes sebesar 12,387 menjadi 40,84 pada saat postes; 2). Pembelajaran Experiental Learning dapat meningkatkan perubahan konsepsi siswa dengan nilai n-gain sebesar 0,596 yang termasuk kategori sedang. Pembelajaran Experiental Learning juga meningkatkan pemahaman konsep siswa dari 5,16\% menjadi 55\%; 3). Siswa kelas eksperimen yang mendapatkan perlakuan model pembelajaran Experiental Learning menunjukkan antusiasme terhadap pembelajaran dengan menjawab rata-rata skala angket sikap sebesar 2,92. Implikasi dari penelitian ini adalah 1). Model pembelajaran Expereintal Learning dapat digunakan sebagai model pembelajaran alternatif untuk merubah dan meningkatkan pemahaman konsep siswa pada materi sifat-sifat cahaya; 2). Tes kognitif berupa three tier test terbukti dapat digunakan sebagai alat ukur perubahan konsepsi siswa; 3) Model pembelajaran Experiental Learning dapat digunakan sebagai kegiatan belajar yang menunjang proses pembelajaran yang menyenangkan, saintifik, dan memberikan hasil pemahaman konsep yang baik.
\end{abstract}

Kata kunci :experiental learning, miskonsepsi, perubahan konsep

\begin{abstract}
This research was motivated by the lack of the quality of learning and by the wrongly conducted learning which focused more on the content rather than the process. This type of learning, especially on the process of learning light properties, has tilted the process towards conceptual memorizing which could lead to the failure in making connections between what were being studied. This topic is considered to be the type of material that should be taught using experimental method. This research used a quasi-experimental design with pretest-postest group design. Sample of this study were fifth grade students at one elementary school in the District of KutawaringinBandung. In total, there were 161 respondents which were drawn randomly without changing the conditions class. The sample was taken from the VA classes totaling 31 student from control class, and 31 student in VB from experimental one. The instrument used in this study consisted of concept understanding test. The results showed that : 1) Experiental Learning models positively affected students' understanding. It was seen from the chances of average scores 12,387 (pretest) and 40,84 (postest); 2). Experiental Learning model could improve student's conceptual change showed by its n-gain (0,596 which fell within the medium category). Experiental Learning model also improved conceptual understanding ( 5,16\% to 55\%); 3). Student's in Experiental Learning class showed enthusiasm towards learning (proved by 2,92 attitude scale quistionanaire score. The implications of this reserach is 1). Experiental Learning model could be used as an alternative learning model in changing and improving student's conceptual understanding of light; 2). Cognitive test in the form three-tier test proved that it could be used as a measuring tool of conceptual changes experienced by the students; 3) Experiental Learning model could be used as a fun, scientific, and rewarding learning activity.
\end{abstract}

Keywords:experiental learning, misconception, changing of concept 


\section{PENDAHULUAN}

Pendidikan didefinisikan sebagai usaha sadar dan terencana untuk mewujudkan suasana belajar dan proses pembelajaran yang mengembangkan potensi diri siswa untuk memliki kekuatan spiritual, keagamaan, pengendalian diri, kecerdasan, akhlak mulia, serta keterampilan diri (UndangUndang Dasar RI No. 20 Tahun 2003 tentang SISDIKNAS). IPA sebagai salah satu mata pelajaran yang ada pada semua tingkatan jenjang pendidikan yang seharusnya dapat memberikan kontribusi dalam membangun SDA manusia yang berkualitas. Salah satu masalah yang dihadapi pendidikan saat ini adalahlemahnyakualitasprosespembelajaran. Proses pembelajaran masih bersifat hapalan yang berakibat pada lebih mementingkan isi daripada proses (Holmqvist, 2014). Selain itu siswa pun kurang diarahkan pada proses pembelajaran yang menghubungkan materi dengan kehidupan sehari-hari siswa. Hal ini menyebabkan siswa lebih mudah lupa dan tidak bisa menguhubungkan satu konsep dengan konsep yang lain, untuk itu perlu adanya penerapan strategi, model, metode pembelajaran yang bervariatif salah satunya pembelajaran model Experiental Learning (Kolb \& Kolb, 2015:435).

Selain itu, kajian tentang lemahnya pendidikan dalam bidang IPA diperkuat juga oleh hasil penelitian dari Trends in International Mathematics and Science Study (TIMSS), (2011) yang menunjukkan bahwa nilai rata-rata siswa kelas VIII menempati urutan ke-38 dari 46 negara. Hasil sains pun bahkan tidak kalah mengcewakan, Indonesia berada di urutan ke-40 dari 42 negara. Bahkan berada di bawah palestina yang kondisi negaranya sedang berada dalam konflik berkepanjangan dengan Israel. Dalam IPA siswa diajarkan untuk mencari tahu tentang alam semesta secara sistematis untuk menguasai pengetahuan, dan memiliki sikap ilmiah Wonoharjo (2012:11). Kajian materi IPA menekankan pada pemberian pengalaman belajar langsung dan kegiatan praktis Trianto (2012:56). Mengingat bahan kajian IPA tentang alam semesta dan memberikan pengalaman belajar langsung serta kegiatan praktis maka sebelum pembelajaran formal di kelas sangat memungkinkan siswa memliki pengetahuan awal terutama pada materi sifat-sifat cahaya. Pengetahuan awal ini bisa saja sesuai atau tidak sesuai dengan pengetahuan IPA yang dimaksud para ilmuwan. Dalam literatur disebut prakonsepsi siswa atau miskonsepsi (Hammer, 2015; Hasan, Bagayoko, \& Kelley, 2012; Allen \& Coole, 2012). Untuk mengatasi miskonsepsi yang sering dialami siswa diperlukan sebuah penerapan model pembelajaran yang dapat memberikan pemahaman kepada siswa terutama dalam konsep sifat-sifat cahaya, yakni salah satunya adalah model pembelajaran Experiental Learning (Robert J Sternberg \& Li-Fang Zhang, 2013:201).

Belajar berdasarkan pengalaman lebih terpusat pada pengalaman siswa yang bersifat terbuka dan siswa mampu membimbing dirinya sendiri. Dalam model $E L$, diperkenalkan konsep pada siswa melalui masalah, dimana masalah tersebut merupakan fenomena-fenomena yang sering dialami oleh siswa. Seperti hasil penelitian dari Dale (2013:92) siswa dapat lebih mengetahui lebih banyak informasi tentang apa yang mereka "kerjakan". Edgar Dale juga menjelaskan experiental learning merupakan pengalaman yang diperoleh siswa sebagai hasil aktivitas sendiri, siswa berhubungan langsung dengan objek yang hendak dipelajari. Dengan model EL, siswa dapat memahami konsep-konsep yang dapat mereka gunakan untuk memecahkan masalah dengan berbagai penjelasan, sehingga kesulitan siswa untuk memahami konsep materi cahaya dapat diatasi dengan model ini. Hal ini sesuai hasil penelitian Syafriani (2013:56) mengatakan bahwa penerapan model pembelajaran berbasis pengalaman (Experiental Learning) dengan pendekatan inkuiri dapat meningkatkan keterampilan 
proses sains materi cahaya pada dua kelas eskperimen siswa SMP dengan kategori sedang.

Berdasarkan uraian diatas, penulis tertarik untuk meneliti bagaimana penerapan model pembelajaran berbasis Experiental Learning terhadap perubahan konsep siswa pada materi sifat-sifat cahaya. Adapun tujuan penelitian ini adalah untuk "Mengetahui pengaruh model pembelajaran Experiental Learning terhadap perubahan konsepsi siswa pada materi sifat-sifat cahaya".

\section{METODOLOGI PENELITIAN Metode dan Desain Penelitian}

Desain ekperimen yang digunakan adalah pre-test post-test control group design (Fraenkel, Wallen, \& Hyun, 2015), dimana penentuan kelas kontrol dilakukan secara acak. Kelas eksperimen diberikan perlakuan pembelajaran dengan model $E L$ dan kelas kontrol dengan model pembelajaran konvensional. Jumlah populasi dalam penelitian ini sebanyak 31 orang kelas kontrol dan 31 orang kelas eksperimen. Sampel di ambil pada salah satu SD Negeri yang ada di Kecamatan Kutawaringin Kabupaten Bandung. Secara bagan desain penelitian yang digunakan dapat digambarkan pada Tabel 1.

Tabel 1

Desain Penelitian

\begin{tabular}{lccc}
\hline Kelompok & Pre-test & Perlakuan & Post-test \\
\hline eksperimen & $\mathrm{O}$ & $\mathrm{X}_{1}$ & $\mathrm{O}$ \\
\hline kontrol & $\mathrm{O}$ & $\mathrm{X}_{2}$ & $\mathrm{O}$ \\
\hline
\end{tabular}

Keterangan ;

O ; Pre-Test dan Post-test untuk melihat perubahan konsepsi siswa terkait materi sifat-sifat cahaya

$\mathrm{X}_{1}$; Perlakuan berupa pembelajaran berbasis pengalaman

$\mathrm{X}_{2}$; Perlakuan berupa pembelajaran konvensional

\section{Instrumen Penelitian}

Untuk mendapatkan data yang diinginkan, peneliti menggunakan isntrumen berupa lembar tes pemahaman konsep, lembar pengamatan (observasi) dan tes skala sikap.

\section{Teknik Pengumpulan Data}

Adapun teknik pengumpulan data yang dilakkan pada penelitian ini dapat dilihat dari tabel 2.

Tabel 2

Teknik Pengumpulan Data

\section{ANALISIS INSTRUMEN \\ Analisis Validitas Butir Soal}

Validitas butir soal adalah suatu ukuran yang menunjukkan tingkat kevalidan atau kesahihan butir soal yang digunakan. Sebuah soal dikatakan valid apabila mampu mengukur apa yang hendak diukur dan dapat mengungkapkan data dari variabel yang diteliti secara tepat. Nilai validitas daoat ditentukan dengan menentukan koefisien product moment.

\section{Reliabilitas Intrumen}

Uji reliabilitas instrumen tes bertujuan untuk mengukur tingkat reliabel soal yang digunakan. Setelah dihitung angka koefieien korelasinya diinterpretasikan dengan kriteria koefisien reliabilitas tabel 3.

Tabel 3

Klasifikasi Koefisien Reliabilitas

\begin{tabular}{cc}
\hline Koefisien korelasi & Interpretasi \\
\hline $0,00-0,20$ & $\begin{array}{c}\text { Hampir tidak ada } \\
\text { korelasi }\end{array}$ \\
\hline $0,20-0,40$ & Rendah \\
\hline $0,41-0,60$ & Cukup \\
\hline $0,61-0,80$ & Tinggi \\
\hline $0,80-1,00$ & Sangat tinggi \\
\hline
\end{tabular}




\section{Tingkat Kesukaran Butir Soal}

Untuk mengetahui tingkat kesukaran sebuah soal maka dilakukan uji tingkat kemudahan. Tingkat kesukaran soal diperoleh, kemudian diinterpretasikan dengan menggunakan kriteria tabel 4.

Tabel 4

Klasifikasi Tingkat Kesukaran

\begin{tabular}{cc}
\hline $\begin{array}{c}\text { Koefisien tingkat } \\
\text { kesukaran }\end{array}$ & $\begin{array}{c}\text { Kriteria tingkat } \\
\text { kesukaran }\end{array}$ \\
\hline $0,00-0,30$ & Sukar \\
\hline $0,30-0,70$ & Sedang \\
\hline $0,71-1,00$ & Mudah \\
\hline
\end{tabular}

Sumber: Wahyudin (2006; hlm. 95)

\section{Analisis Daya Pembeda Soal}

Daya pembeda digunakan untuk mengetahui kesanggupan soal untuk membedakan siswa yang tergolong mampu atau tingkat tinggi prestasinya dan siswa yang kurang atau lemah prestasinya.

Nilai yang diperoleh kemudian diinterpretasikan pada klasifikasi daya pembeda adalah tabel 5 .

\section{Tabel 5}

Klasifikasi Daya Pembeda

\begin{tabular}{cc}
\hline Koefisien korelasi & Interpretasi \\
\hline $0,00-0,20$ & Jelek \\
\hline $0,21-0,40$ & Cukup \\
\hline $0,41-0,70$ & Baik \\
\hline $0,71-1,00$ & Baik sekali \\
\hline
\end{tabular}

\section{Teknik Pengolahan Data}

Analisis data kuantitatif

Menghitung skor pretest dan postest pada

kelas kontrol dan kelas eksperimen.

Menghitung normalitas antara skor pretest

dan postest

Melakukan uji homogenitas

Uji-t

Menentukan N-gain

Menentukan N-gain untuk mengetahui peningkatan pemahan konsep, menurut Hake dalam Yulianti (2012, hlm 43) untuk menghitung $\mathrm{N}$-gain menggunakan rumus:

$$
\mathrm{N} \text {-gain }=\text { Skor test akhir-skor test awal }
$$

Kriteria N-gain adalah sebagai berikut : Tabel 6

Kategori Tingkat N-Gain

\begin{tabular}{cc}
\hline Normalisasi N-gain & Kriteria \\
\hline $\mathrm{g}>07$ & Tinggi \\
\hline $0,3, \leq \mathrm{g} \leq 7$ & Sedang \\
\hline $\mathrm{g}<0,3$ & Rendah \\
\hline
\end{tabular}

\section{Pengolahan Data Perubahan Konsep}

\section{Siswa}

a. Melakukan penilaian terhadap hasil jawaban siswa pretest dan postest serta tabulasi nilai masing-masing siswa.

b. Membuat koding dan memisahkan jawaban siswa pretest dan postest yang paham konsep, tidak paham konsep, miskonsepsi dan eror.

c. Menghitung presentase siswa yang menjawab paham konsep, tidak paham konsep, eror dan miskonsepsi pretest dan posttest kelas eksperimen juga kelas kontrol.

d. Mendeksripsikan hasil presentase perubahan konsepsi siswa pada kelas eksperimen dan kelas kontrol untuk setiap indikator soal.

\section{Pengolahan Data Kualitatif}

a. Analisis data skala sikap

b. Analisis lembar observasi

\section{HASIL DAN PEMBAHASAN \\ Pemahaman Konsep Siswa Kelas \\ Konvensional dan Kelas Model \\ Pembelajaran $E L$}

Tabel 7

Pemahaman Konsep Siswa Kelas Eksperimen dan Kelas Kontrol

\begin{tabular}{ccccc}
\hline \multirow{2}{*}{ Kelas } & \multicolumn{4}{c}{ Pemahaman awal (\%) } \\
\cline { 2 - 5 } & Paham Konsep & Miskonsepsi & $\begin{array}{c}\text { Tidak Paham } \\
\text { Konsep }\end{array}$ & Eror \\
\hline Kontrol & 5,10 & 13,03 & 78,06 & 3,71 \\
\hline Eksperimen & 2,10 & 14,25 & 79,68 & 4,03 \\
\hline Kontrol & 36,94 & Pemahaman Akhir (\%) & 5,81 \\
\hline Eksperimen & 55,00 & 43,96 & 13,39 & 0,32 \\
\hline
\end{tabular}


Tabel 8

Pemahaman Konsep

\begin{tabular}{ccccc}
\hline \multirow{2}{*}{ Kelas } & \multicolumn{4}{c}{ Pemahaman awal (\%) } \\
\cline { 2 - 5 } & Paham Konsep & Miskonsepsi & Tidak Paham Konsep & Eror \\
\hline Kontrol & 5,10 & 13,03 & 78,06 & 3,71 \\
\hline Eksperimen & 2,10 & 14,25 & 79,68 & 4,03 \\
\hline \multicolumn{5}{c}{ Pemahaman Akhir (\%) } \\
\hline Kontrol & 36,94 & 43,96 & 13,39 & 5,81 \\
\hline Eksperimen & 55,00 & 35,98 & 8,71 & 0,32 \\
\hline
\end{tabular}

\section{Perubahan pemahaman konsep}

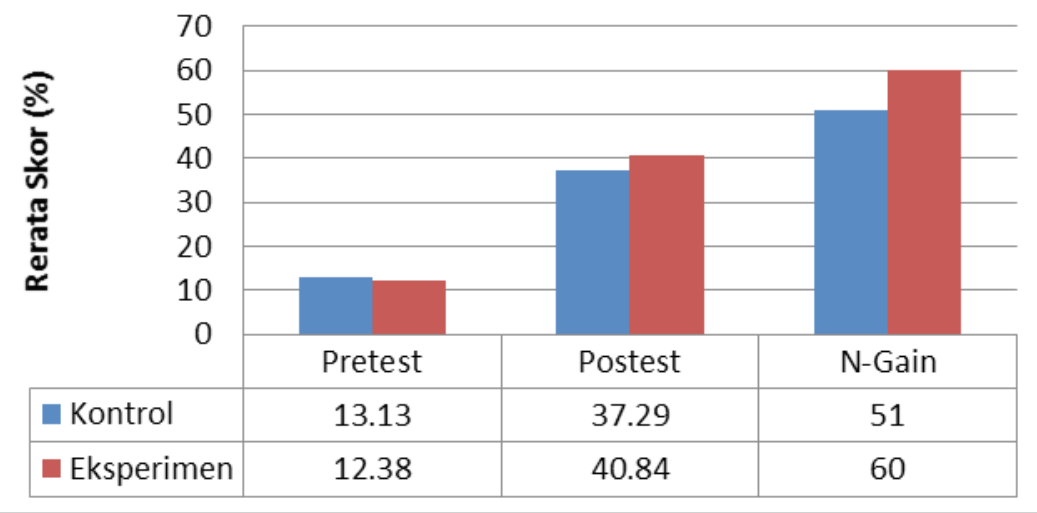

Gambar 1

Perbandingan Nilai Pre-Test dan Post-Test dan Nilai Gain Dinormalisasi Kelas Kontrol dan Kelas Eksperimen

Pemahaman Awal; dilihat dari tabel siswa yang mengalami tidak paham konsep, eror dan miskonsepsi sangatlah tinggi, jelaslah terlihat bahwa pada pemahaman awal ratarata siswa masih belum memiliki konsep di awal pembelajaran.

Pemahaman Akhir; dilihat dari tabel masih terdapat miskonsepsi terjadi pada kelas kontrol dan eksperimen, siswa menjawab benar pada tier $1+$ tier 3 tetapi tier 2 siswa menjawab salah. Sekalipun demikian miskonsepsi masih dapat dikatakan lebih baik daripada tidak memahami konsep. Akan tetapi, secara keseluruhan bahwa setengah bagian siswa dari populasi dapat memahami konsep.

\section{Perubahan Pemahaman Konsep Tiap Indikator Soal}

Pembelajaran konvensional; pada grafik yang telah dipaparkan sebelumnya, pada awal tes siswa belum mengetahui apa saja yang harus dipaparkan dalam menjawab soal, secara umum siswa belum memiliki informasi awal mengenai materi yang ditanyakan pada soal, maka siswa menjawab soal dengan salah atau tidak tepat pada awal tes.

Dengan pembelajaran konvensional pada umumnya siswa mengalami perbahan konsep dari tidak paham menjadi paham konsep ataupun dari tidak paham konsep menjadi miskonsepsi, miskonsepsi tersebut disebabkan karena siswa kurang mencerna informasi yang disampaikan oleh guru meskipun pada dasarnya metode ceramah dapat membuat konsentrasi siswa lebih terpusat kepada guru, namun karena beberapa faktor pembelajaran mengakibatkan rasa bosan. Miskonsepsi tertinggi terjadi pada indikator 5, 6 dan 7 bahkan masih ditemukan pada indikator tersebut siswa yang menjawab Eror.

Pembelajaran dengan model $E L$; pada tes awal pembelajaran di kelas eksperimen pun 
mayoritas siswa tidak tahu cara menjawab soal yang diberikan sehingga terdapat banyak kesalahan menjawab soal, bahkan eror, hal ini disebabkan karena siswa menjawab dengan cara asal menebak. Meskipun ada beberapa siswa yang menjawab soal dengan tepat dikarenakan siswa telah memiliki konsep sebelumnya pada materi yang diberikan (Sriani \& Sutama, 2015).

Setelah diberikan perlakuan model jumlah siswa yang mengalami miskonsepsi mengalami penurunan signifikan, hal ini disebabkan karena penerapan model EL memberikan pengalaman belajar siswa lebih banyak, siswa dilatih untuk terfokus dalam pemecahan materi,siswa dituntut untuk menjawab permasalahan dengan tepat, mengungkapkan informasi yang mereka miliki sehingga terjadi pertukaran ilmu yang lebih dapat dicerna oleh siswa sebagai pelajar.

\section{Analisis Skala Sikap}

Tabel 9

Skala Sikap

\begin{tabular}{lccc}
\hline Indikator Skala Sikap & Rata-rata & Keputusan & Ket \\
\hline Sikap siswa menyukai bahasan materi sifat-sifat cahaya & 3,05 & positif & Ha diterima \\
\hline Sikap siswa terhadap model pembelajaran $E l$ & 2,95 & positif & Ha diterima \\
\hline Sikap siswa terhadap peningkatan perubahan konsep & 2,92 & positif & Ha diterima \\
\hline
\end{tabular}

\section{Sikap Siswa Terhadap Model Pembelajaran $\boldsymbol{E L}$}

Angket skala sikap hanya diberikan kepada kelas eksperimen karena skala sikap ditujukan untuk mengukur bagaimana proses pembelajaran menunjang hasil belajar siswa dan memperlihatkan kegiatan siswa selama pembelajaran berlangsung. Ada 3 indikator yang telah dirangkum dari 20 pertanyaan yang telah diajukan kepada siswa diantaranya: 1) mengenai sikap siswa mengenai bahasan materi sifat-sifat cahaya; 2) sikap siswa terhadap model pembelajaran $E L ; 3)$ sikap siswa terhadap peningkatan perubahan konsep. Hasil skala sikap menunjukkan bahwa siswa bersikap positif terhadap pembelajaran dengan model Experiental Learning.

\section{SIMPULAN}

Berdasarkan Penelitian yang dilakukan, Pembelajaran berbasis Pengalaman berpengaruh terhadap perubahan konsepsi peserta didik dengan rincian sebagai berikut: 1) Pembelajaran berbasis pengalaman merubah pemahaman konsep siswa dilihat dari nilai rata-rata kelas yang meningkat saat pretes 12,387 menjadi 40,84 pada saat postes, 2) Pembelajaran berbasis pengalaman dapat meningkatkan perubahan konsepsi peserta didik dengan nilai n-gain sebesar 0,596 yang termasuk kedalam kategori sedang. Pembelajaran berbasis pengalaman juga meningkatkan pemahaman konsepsi siswa dari $5,16 \%$ menjadi $55 \%, 3$ ) Siswa kelas eksperimen yang mendapatkan model pembelajaran berbasis pengalaman menunjukkan antusiasme terhadap pembelajaran dengan menjawab rata-rata angket sikap sebesar 2,92.

\section{REKOMENDASI}

Berdasarkan penelitian yang dilakukan, pembelajaran berbasis pengalaman memberikan dampak yang positif bagi hasil belajar siswa, serta meningkatkan pemahaman konsep dan mengurangi miskonsepsi, serta tidak memahami konsep. Implikasi dari penelitian ini adalah sebagai berikut: 1) Model Pembelajaran berbasis pengalaman dapat digunakan sebagai model pembelajaran alternatif untuk merubah dan meningkatkan pemahaman konsep siswa pada materi pembelajaran sifat - sifat cahaya, 2) Test kognitif berupa three tier test terbukti dapat digunakan sebagai alat ukur perubahan konsepsi siswa, 3) Model pembelajaran berbasis pengalaman dapat digunakan 
sebagai kegiatan belajar yang menunjang proses pembelajaran yang menyenangkan, saintifik, dan memberikan hasil pemahaman konsep yang baik.

\section{DAFTAR RUJUKAN}

Allen, M., \& Coole, H. (2012). Experimenter Confirmation Bias and the Correction of Science Misconceptions. Journal of Science Teacher Education, 23(4), 387-405.

Dale, E. (2013). Audiovisual methods in teaching. (6d ed.). New York: Holt, Rinehart and Winston.

Fraenkel, J. R., Wallen, N. E., \& Hyun, H. H. (2015). How to design and evaluate research in education. McGrawHill Humanities/Social Sciences/Languages.

Hammer, D. (2015). More than misconceptions: Multiple perspectives on student knowledge and reasoning, and an appropriate role for education research. American Journal of Physics, 64(10), 1316-1325.

Hasan, S., Bagayoko, D., \& Kelley, E. (2012). Misconceptions and the certainty of response index (CRI). Physics Education, 34, 294-299.

Holmqvist, M. (2014). Experiential Learning Processes of Exploitation and Exploration Within and Between Organizations: An Empirical Study of Product Development. Organization Science, 15(1), 70-81.

Kolb, A. Y., \& Kolb, D. A. (2015). Learning Styles and Learning Spaces: Enhancing Experiential Learning in Higher Education. Academy of Management Learning \& Education, 4(2), 193-212.

Robert J Sternberg, \& Li-Fang Zhang. (2013). Perspectives on Thinking, Learning, and Cognitive Styles. New York: Lawrence Erlbaum Associates, Inc.

Sriani, N., \& Sutama, I. (2015). Penerapan Model Pembelajaran Experiential Learning Untuk Meningkatkan Kemampuan Menulis Paragraf Deskripsi Pada Siswa. Pendidikan Bahasa Dan ..., 1(2), 14-21.

Syafriani, S. (2013). Penerapan Model Pembelajaran Berbasis Pengalaman Dengan Pendekatan Inkuiri Pada Materi Cahaya Untuk Meningkatkan. Jurnal Pendidikan, 3(2), 50-68.

Trends in International Mathematics and Science Study (TIMSS). (2014). International Association for The Evaluation of Educational Achievment. Lynch School of Education. Boston: College.

Trianto. (2012). Model Pembelajaran Terpadu: Konsep, Strategi, dan Implementasi dalam Kurikulum Tingkat Satuan Pendidikan (KTSP). Jakarta: Bumi Aksara.

Undang-undang Dasar. (2013). Undang-undang Dasar. 2013. Tentang Sistem Pendidikan Nasional. Jakarta.

Wonoharjo, S. (2012). Dasar-Dasar Sains : Menciptakan Masyarakat Sadar Sains. Jakarta: Indeks. 